\title{
The Opossum Didelphis virginiana as a Synanthropic Reservoir of Trypanosoma cruzi in Dzidzilché, Yucatán, México
}

\author{
Hugo A Ruiz-Piña/ ${ }^{+}$, Alejandro Cruz-Reyes*
}

\begin{abstract}
Laboratorio de Parasitología, Centro de Investigaciones Regionales “Dr. Hideyo Noguchi”, Universidad Autónoma de Yucatán, Apartado Postal 1247-A, C.P. 97240, Mérida, Yucatán, México *Laboratorio de Helmintología, Instituto de Biología, Universidad Nacional Autónoma de México, México, D.F., México
\end{abstract}

\begin{abstract}
In México, the role of mammals in the transmission cycle of Trypanosoma cruzi is poorly known. In the State of Yucatán, an endemic area of Chagas disease, both Didelphis virginiana and D. marsupialis occur sympatrically. However, until now, only the former species had been found infected with $\mathrm{T}$. cruzi. To evaluate the role of $\mathrm{D}$. virginiana in a peridomestic transmission, nine periods of capture-recapture were performed around the village of Dzidzilché, Yucatán. The sex, age, reproductive status, location, and presence of infection with T. cruzi were recorded for each opossum. The chromosome morphology was used to identify the opossum species. T. cruzi was identified by the presence of pseudocysts of amastigotes in cardiac muscle fibers of Balb/c mice inoculated with strains isolated from opossums. However, xenodiagnosis was the best diagnostic method. Triatoma dimidiata, the vector, were collected in and around the opossums' nests, and human dwellings; and were checked for T. cruzi. From 102 blood samples of D. virginiana examined 55 (53.9\%) were positive to T. cruzi, the only two D. marsupialis captured were negative. Significant differences were found between infection, and both sex and reproductive condition. Eight out of 14 triatomines collected in peridomestic nests (57.1\%), and 32 of 197 captured inside houses (16.3\%) were found infected, suggesting a peridomestic transmission. The statistically high abundance of infected opossums and triatomines during the dry season (March to May) suggested the existence of a seasonality in the peridomestic transmission of T. cruzi in Dzidzilché.
\end{abstract}

Key words: Didelphis virginiana - Trypanosoma cruzi - Chagas disease - epidemiology - synanthropic reservoir - Yucatán México

Chagas disease is an endemic zoonosis in the American Continent, where 16 to 18 million of people are estimated to be infected, about 45,000 die each year, and 90 million are at risk ( $25 \%$ of Latin-American population) (WHO 1991). Chagas disease is caused by the hemoflagellate Trypanosoma cruzi, which is transmitted by hematophagous triatomine insects (Hemiptera: Reduviidae), and maintained by wild and synanthropic mammals. Opossums of the genus Didelphis (Marsupialia: Didelphimorphia) are considered the most important wild reservoirs of $T$. cruzi due to their wide distribution, their great adaptive capacity, and their close association with human dwellings (WHO 1991).

In México, very few studies on reservoirs of $T$. cruzi have been carried out. Most of them have published the presence of infection, based on little sample-size, random capture-periods, and sometimes misidentified species of mammal (Aguirre Pequeño 1947, Salazar Schettino et al. 1987, Galaviz-Silva \& Arredondo-Cantú 1992). Thus, the role of Mexican mammals in sylvatic or peridomestic cycles of transmission of $T$. cruzi is not well known.

This study was supported by a PhD grant from the "Consejo Nacional de Ciencia y Tecnología" of the Mexican government ${ }^{+}$Corresponding author. Fax: +52-99-236-120. E-mail: rpina@tunku.uady.mx

Received 18 June 2001

Accepted 17 April 2002
The State of Yucatán is an endemic area of Chagas disease (Barrera-Pérez et al. 1990), where the main vector is Triatoma dimidiata (Guzmán-Marín et al. 1992). In this area, D. marsupialis and D. virginiana are sympatric, however, their specific importance as reservoir is not well established. Even though, D. virginiana is thought to be the most abundant opossum species in northern Yucatán (Jones et al. 1974), only D. marsupialis has been found infected with T. cruzi (Zavala-Velázquez et al. 1996).

In this study, we determined the role of $D$. virginiana as the main synanthropic reservoir and documented a seasonality in the transmission of T. cruzi in Dzidzilché, Yucatán, México.

\section{MATERIALS AND METHODS}

Study area - This study was carried out from April 1996 to May 1998 in Dzidzilché, a small village located 25 $\mathrm{km}$ NW of Mérida, and $10 \mathrm{~m}$ above sea level $\left(21^{\circ} 08^{\prime} \mathrm{N}\right.$, $89^{\circ} 41^{\prime} \mathrm{W}$ ) (Fig. 1). Dzidzilché had 250 inhabitants grouped in 49 households. Fruit trees such as Mangifera inca (mango) Manilkara achras (gumtree), Spondias purpurea (plum), Citrus aurantium (orange), and Carica papaya (papaya), were common in the courtyards.

The vegetation of the area included abandoned sisal plantations and low-height thorn forest. The climate was warm and humid with a mean temperature of $25.4^{\circ} \mathrm{C}$, and an annual rainfall of $940 \mathrm{~mm}$. It presented a rainy season from the end of June to December, and a dry season from January to mid-June (Flores \& Espejel 1994).

Opossums capture - Opossums were captured in a $4 \mathrm{x}$ 4 grid of livetraps (66 x $23 \times 23 \mathrm{~cm}$, Tomahawk Live Trap 


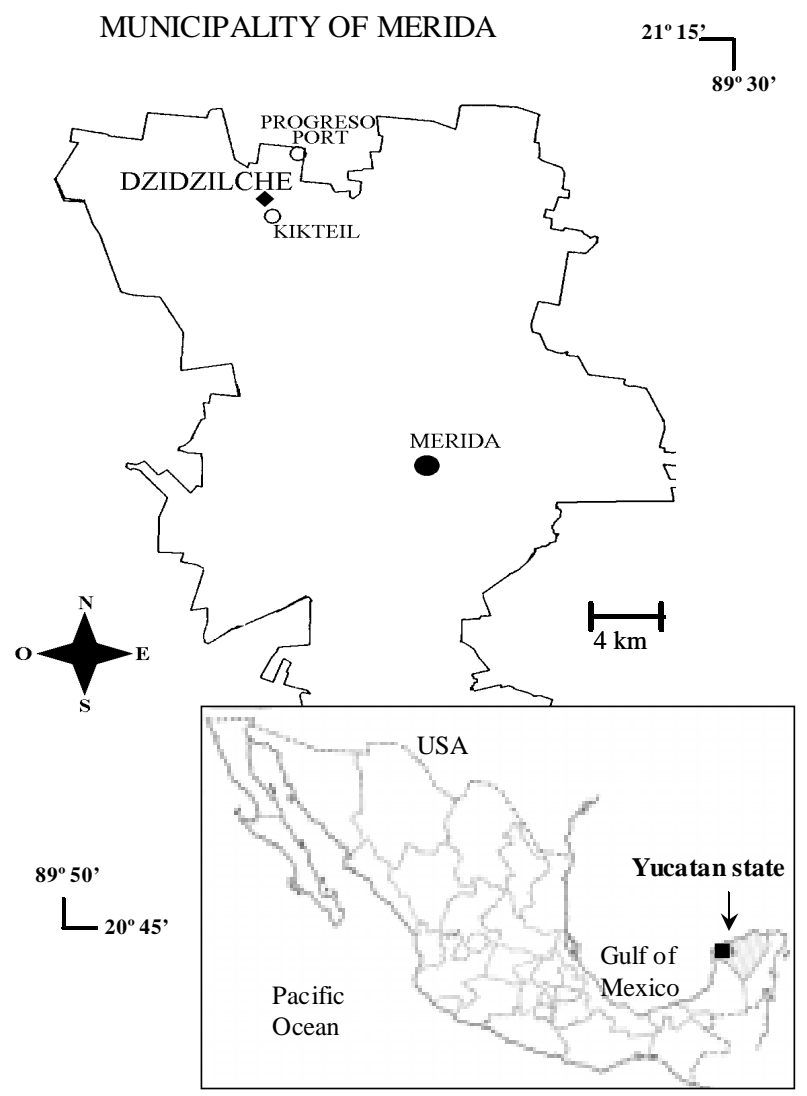

Fig. 1: map of the study area, Dzidzilché in the northwest of the State of Yucatán, México.

Co.) set at $250 \mathrm{~m}$ intervals (total 156 hectares), including Dzidzilché and its surroundings. Traps were baited with seasonal fruits (pineapple and sapota) in the afternoon and revised early the morning after. We defined as peridomestic traps those set less than $50 \mathrm{~m}$ from a house, including those in courtyards.

A capture-recapture method (Begon 1979) was used during nine periods. Each period lasted three weeks: during the first week, animals were captured, marked using a $2 \mathrm{~mm}$ ear-punch, and released in the site of capture; capture was interrupted the following week to allow dispersion; and the third week, capture and marking were resumed. After 51 days, a new capture period was initiated.

Identity of opossums - Identification was based on coloration of the hair, mainly of the cheek region (white in $D$. virginiana, and pale yellow to buffy orange in $D$. marsupialis). Additionally, we used the morphology of chromosomes from metaphasic lymphocytes obtained from blood sample to corroborate taxonomic identity of opossums (Gardner 1973).

Population characteristics - Opossums were sexed, and three age-classes were defined based on total length, and teeth eruption sequence (juveniles, 3-5 months old; subadults, 6-8; and adults, older than 9 months) (Petrides 1949). Reproductive status was determined in females by the presence of embryos inside the marsupium. Subadults and adults males were considered sexually mature and capable of breeding (Hunsaker 1977).
The movement of some opossums was measured attaching a $300 \mathrm{~m}$ spool line at the base of tail and tracking them after release (Miles 1976). Opossums were followed to locate their nests (sites used for five or more consecutive days) or refuges (other sites). A ten-minute advantage was given to the opossums after release to lower the stress of being followed and to obtain more natural results. Distances were calculated by measuring the linear distances between consecutive captures.

Infection in opossums - All the opossums captured including recaptured ones during the following working period, were anesthetized via intramuscular with xylazine $(0.25 \mathrm{mg} / \mathrm{kg}$ body weight $)$ mixed with ketamine $(25 \mathrm{mg} /$ kg)(Pietrzak \& Pung 1998). Blood (2-3 ml) was extracted by cardiac puncture and stored in a heparinized glass tube.

We used three procedures to detect infection in opossums. The two first methods were microscopic: (a) a drop of fresh blood and (b) the buffy coat obtained after centrifugation $(30 \mathrm{~min}$ at $100 \mathrm{~g}$ ) in capillary tubes. The drop of blood and the buffy coat were diluted 1:1 in Phosphate Buffered Solution (PBS) (pH 7.2) and examined for motile trypomastigotes under light microscope (X40). The third procedure was the xenodiagnosis using five triatomines of fourth or fifth instars nymphs of $T$. dimidiata, obtained from our laboratory-reared colony. The five triatomines were placed on the belly of opossums and allowed to feed for $20 \mathrm{~min}$. Every 15 days for two months, drops of urine or feces of triatomines were obtained after bloodmeals from anesthetized adult pigeons, and diluted in PBS for microscopic examinations. An opossum was considered positive to $T$. cruzi if the parasite was found by any of those three methods. Because D. virginiana can maintain natural and experimentally infection by local strains of T. cruzi at least for two years (unpublished data), generally once an opossum was proved infected it was no more checked for infection until the end of the study.

Intracellular invasion by parasites was microscopically observed to confirm the identity of $T$. cruzi by inoculating intraperitoneally Balb/C mice with infected triatomine feces or urine suspended in PBS. Every week after inoculation, a drop of blood was obtained from the mice tail, diluted 1:1 in PBS, and microscopically checked for parasitemia. Two months after inoculation the mice were euthanazed with chloroform. Tissue samples from the heart of each mouse were fixed in buffered $10 \%$ formalin, imbedded in paraffin, cut into $5 \mu$ sections, and stained with hematoxilina-eosina. At the end of the study, hearts of some opossums processed with an overdose of Pentobarbital were also examined for T. cruzi nests (Araujo et al. 1996).

Collection and infection in triatomines - Volunteers from 25 households collected randomly adult triatomines during the study in and around the house. Latex gloves and forceps were provided to prevent an accidentally infection during the insect manipulation. Both refuges and nests of opossums were also checked for triatomines. Captured triatomines were taxonomically identified according to Lent and Wygodzinsky (1979). Infection in triatomines captured was diagnosed similarly to the insects from the xenodiagnosis. 
Statistical analyses - Data of capture, movement, and infection prevalence of the opossums were compared with sex, age, capture sites (peridomestic versus nonperidomestic traps), months, and seasons; using ChiSquare and t Student tests (Epi Info ver. 6.03, and Statgraphics ver. 6.0) with $95 \%$ confidence (Downie \& Heath 1971).

\section{RESULTS}

Identity of opossums - In this study, the coloration characteristics described by Gardner (1973) were not enough to discriminate between $D$. marsupialis and $D$. virginiana. Several individuals presented mixed hair color; thus the chromosome morphology had to be used. $D$. virginiana $(2 \mathrm{n}=22)$ presents six pairs of subtelocentric and four pairs of acrocentic autosomes whereas $D$. marsupialis $(2 \mathrm{n}=22)$ has all acrocentrics (Gardner 1973). Ninety-eight opossums were captured from which 96 were D. virginiana and two D. marsupialis.

Infection in opossums - From 102 blood samples of $D$. virginiana 55 (53.9\%) were infected with T. cruzi (Table I). The two D. marsupialis were not infected.

The percentage of infection differed according to the method used: all the infected opossums were found by xenodiagnosis, while only $52 \%$ and $16 \%$ were detected by the buffy coat and the fresh blood drop methods, respectively.

Prevalence of infection of $D$. virginiana during the nine capture periods ranged from 25 to $66.6 \%$. From the 55 infected opossums, $49(89.1 \%)$ were captured in dry-season periods $\left(\chi^{2}=8.1, \mathrm{p}<0.05\right)($ Table I).

Although females seemed more oftenly infected with $T$. cruzi than males, this difference was not significant $\left(\chi^{2}\right.$ $=4.42, \mathrm{p}>0.05)$. However, most of reproductive females (23 out 24) were found infected during the dry season (February to May) (Table I). We found significant differences among the three age-classes: adult opossums were more oftenly infected $\left(\chi^{2}=27.19, \mathrm{p}<0.05\right)$ (Table I).
The movement of 24 opossums was documented from 38 recaptures, from which 30 were from infected opossums. All opossums recaptured more than once were reproductive females. Females traveled less than males $\left(\chi^{2}\right.$ $=23.5, \mathrm{p}<0.05)$, moreover reproductive females moved less than non-reproductive ones $\left(\chi^{2}=17.1, p<0.05\right)$. Infected opossums wandered less than non-infected ones $\left(\chi^{2}=5.5, p<0.05\right)($ Table II), and 57\% (17/30) of the infected opossums were reproductive females. Forty-six of the infected opossums $(83.5 \%)$ were captured in peridomestic traps, and females were predominant in both peridomestic $(56.5 \%)$ and non-peridomestic traps $(77.7 \%)$.

The identity of $T$. cruzi was confirmed by the presence of the pseudocysts in cardiac tissue of opossums and all experimentally infected mice (Figs 2-3). Some isolates were preserved for future genetic studies.

Collection and infection by T. cruzi in triatomines Fourteen triatomines identified as $T$. dimidiata were collected inside 12 nests located in peridomestic habitat, from which 7 adults and 1 fifth instar $(57.1 \%)$ were infected by T. cruzi. The 7 refuges were free of triatomines.

From the 197 T. dimidiata adults collected in or around human houses, 32 (16.2\%) were infected by T. cruzi. Both capture and infection of triatomines were higher during the dry season $(\mathrm{t}=3.1, \mathrm{p}<0.05$ and $\mathrm{t}=4.3, \mathrm{p}<0.05$, respectively)(Table III).

The highest peaks of infected triatomines coincided with the highest capture rate of infected opossums at late dry season and beginning of the rainy one (Fig. 4). In addition, three opossums with a previous negative diagnostic in the dry season (November 1996 and February 1997) were recaptured infected in February 1997.

\section{DISCUSSION}

This study confirmed Gardner's (1973) fear that no external morphological characters reliably differentiate $D$. virginiana from $D$. marsupalis, and highlighted the need of karyotyping in areas of sympatrical distribution of these

\section{TABLE I}

Prevalence of Trypanosoma cruzi in Didelphis virginiana captured during nine periods from April 1996 to May 1998, in relation to season, and three population parameters in Dzidzilché, Yucatán, México

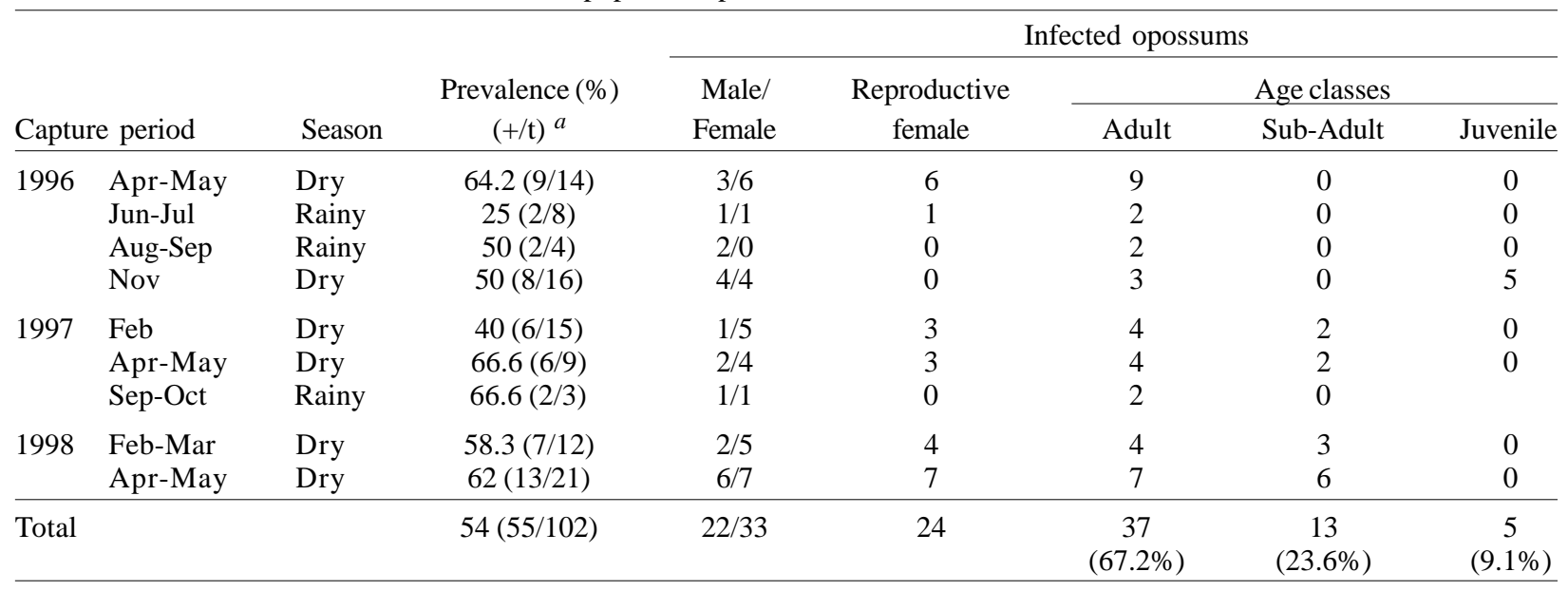

$a$ : infected; t: total captured 

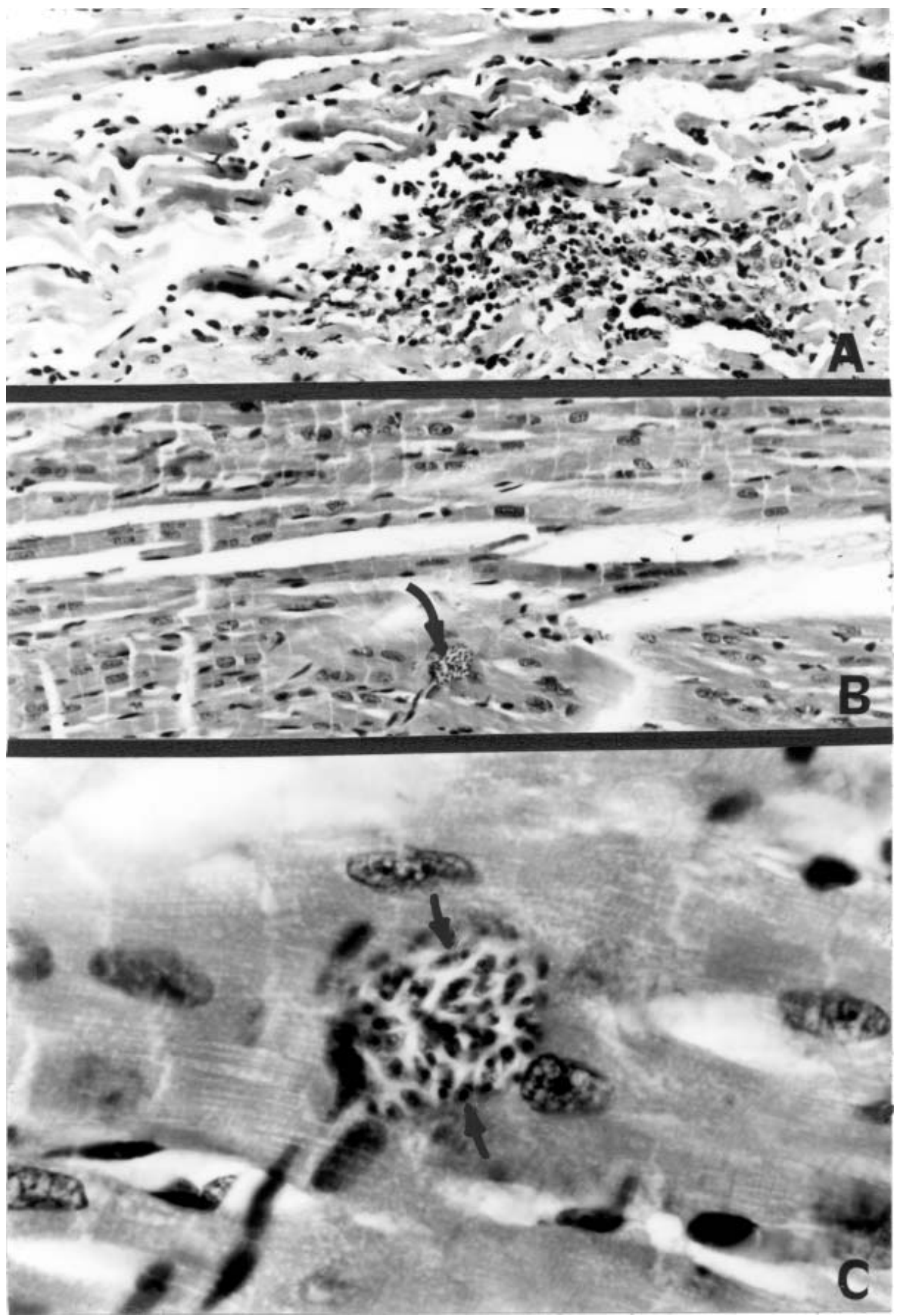

Fig. 2: histopathological lesions in cardiac muscle of opossums (Didelphis virginiana) naturally infected with Trypanosoma cruzi. A: myocardium showing a focus of severe inflammation and moderate fibrosis, X10; B: intracellular pseudocyst of amastigotes, arrow, X40; C: pseudocyst with amastigotes and trypomastigotes showing the nucleus and typical rod-shaped kinetoplast, arrows, X65. H\&E stained 


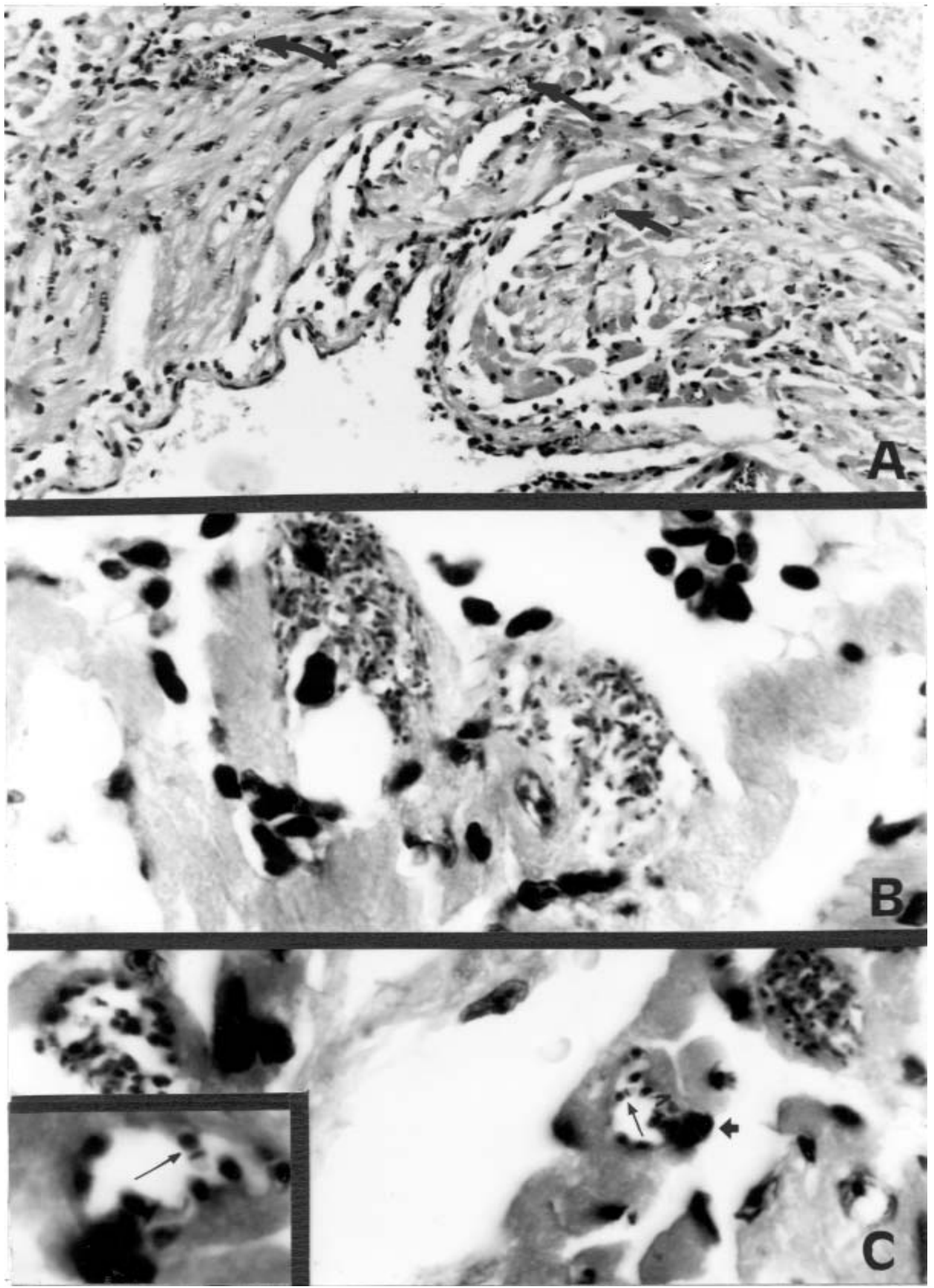

Fig. 3: histopathological lesions in myocardium of Balb/C mice, experimentally infected with Trypanosoma cruzi isolated from feces of triatomine bugs used in the xenodiagnoses procedure. A: pseudocyts of amastigotes randomly dispersed, arrows, surrounded by interstitial inflammation, X10; B: two partially ruptured pseudocyst with amastigotes and trypomastigotes and numerous inflammatory cells, X40; C: three pseudocysts, one of them is invaded by a macrophage, arrows and insert, nucleus and rod-shaped kinetoplast are clearly seen, X65, X100. H\&E stained 
opossums, such as the northern Yucatán Península, México. Thus, all previous studies identifying opossums as reservoirs of $T$. cruzi in such areas should be revised (e.g. Domínguez et al. 1990, Zavala-Velázquez et al. 1996, Solís-Franco et al. 1997). As reported (Jones et al. 1974) we observed the dominance of $D$. virginiana population over D. marsupialis (96:2). In México, natural infection of $D$. virginiana with $T$. cruzi had been reported only from two individuals from Chiapas (Solís-Franco et al. 1997). Thus, we demonstrated for the first time the infection of $D$. virginiana with T. cruzi in the Yucatán Península.

In this study xenodiagnosis was the most reliable test to detect trypanosome infections in wild mammals, which generally present very low parasitemia, even using as few as five triatomines. However, more precise tests, such as serological ones, might increase the infection rate.

The opossum population studied was made of a higher proportion of females. The predominance of females was confirmed with the finding of higher proportion of females in 28 litters comprising 174 embryos (data not shown). The production of more females seemed a population trend of $D$. virginiana in our study area. The reproductive activity of $D$. virginiana was concentrated during the dry season (from February to May), where all infected females, except one, carried embryos. The predominance of females and their reproductive status were two key population parameters that influenced the rate of infection obtained in this study.

Females with embryos traveled lesser around their nests than males (Table II). The greater nest fidelity of reproductive $D$. virginiana during the caring period (Hossler et al. 1994) is probably influenced by the abundance of cultivated fruits as gumtree, mango, plum and papaya from February to June around Dzidzilché. Since we found triatomines only inside peridomestic nests, we can confirm the close relationship between triatomines and opossums as found in other areas of the American continent (Zeledón et al. 1973, Wisnivesky-Colli et al. 1992), and we suggest that triatomines can select the habitat most often used by opossums. Thus, a strong relation among pregnant females, peridomestic nests and triatomines can be established in this study. Previous studies in Yucatán had found opossum blood in the digestive tract of T. dimidiata (Quintal \& Polanco 1977) and opossums are known to get infected by ingesting triatomines as well (Yaeger 1971, Schweigmann et al. 1995); in Costa Rica, Zeledón (1970) associated the presence of $T$. dimidiata inside opossums nests with the high indices of infection found in the vector. Thus, the contact of pregnant females with infected triatomines inside the peridomestic nests would increased exposition to the infection and explains the higher infection rate of reproductive females found in this study.

The rate of infection was higher in triatomines found inside opossum nests $(57.1 \%)$ than in those associated with human dwellings (16.2\%), which highlighted that the transmission cycle of $T$. cruzi took place inside the nests. Similarly, Zeledón et al. (1970) found infected nymphs and adults T. dimidiata inside 12 D. marsupialis nests. In Argentina, Wisnivesky-Colli et al. (1992) captured T. infestans infected by $T$. cruzi inside refuges of $D$. albiventris.
TABLE II

Average of distances traveled by Didelphis virginiana in relation to age, sex, reproductive condition, and infection with Trypanosoma cruzi in Dzidzilché, Yucatán, México, from April 1996 to May 1998 (distance values are presented as Mean \pm SD)

\begin{tabular}{llcc}
\hline Population parameter & $\begin{array}{c}\text { Recapture } \\
\text { frequency }\end{array}$ & $\begin{array}{c}\text { Distance } \\
\text { traveled (m) }\end{array}$ \\
\hline Age & Adult & 30 & $275.6 \pm 50.9$ \\
& Subadult & 6 & $223.5 \pm 115.3$ \\
Sex & Juvenile & 2 & $261.1 \pm 369.2$ \\
& Male & 9 & $362.9^{b} \pm 257.9$ \\
Reproductive statur & Female & 29 & $236.8^{b} \pm 250.4$ \\
\multirow{4}{*}{ Non-reproductive } & Male & 8 & $408.2^{b} \pm 224.8$ \\
& Female & 19 & $212.8^{b} \pm 258.1$ \\
Infection & Male & 1 & $250 \pm 0$ \\
& Female & 10 & $326 \pm 255.1$ \\
& Infected & 27 & $182.1^{b} \pm 233.3$ \\
& Non-infected & 11 & $433^{b} \pm 279.3$ \\
\hline
\end{tabular}

$a: 38 ; b:<0.05$

TABLE III

Prevalence of Trypanosoma cruzi and abundance of Triatoma dimidiata captured during nine periods from April 1996 to May 1998 in relation to season, in Dizdzilché, Yucatán, México

\begin{tabular}{lllcc}
\hline Capture period & $\begin{array}{c}\text { Climatic } \\
\text { season }\end{array}$ & Capture & $\begin{array}{c}\text { Infection } \\
\text { prevalence } \\
(+/ \mathrm{t})^{a}(\%)\end{array}$ \\
\hline 1996 & Apr-May & Dry & 50 & $16(8 / 50)$ \\
& Jun-Jul & Rainy & 5 & $20(1 / 5)$ \\
& Aug-Sep & Rainy & 5 & 0 \\
& Nov & Dry & 0 & 0 \\
1997 & Feb & Dry & 2 & 0 \\
& Apr-May & Dry & 61 & $18.1(11 / 61)$ \\
& Sep-Oct & Rainy & 13 & 0 \\
1998 & Feb-Mar & Dry & 5 & $20(1 / 5)$ \\
& Apr-May & Dry & 56 & $19.6(11 / 56)$ \\
\hline \multicolumn{2}{c}{ Total } & & 197 & $16.2(32 / 197)$ \\
\hline
\end{tabular}

$a$ : infected; t: total captured

The existence of infected triatomines inside houses $(16 \%)$ and the similarity in molecular patterns found in Yucatán strains isolated from opossums and humans (Zavala-Castro et al. 1992) suggest that $D$. virginiana is participating as an infection source for humans as reported for other Latin-American countries (Zeledón 1970, Pinho et al. 2000). Through an ongoing study on human population in the Yucatán Península, we will be able to confirm this hypothesis by comparing molecular characteristics of $T$. cruzi isolated from opossums and humans.

Both the abundance and rate of infection of both the vector and the reservoir during the dry season (Tables I, III, Fig. 4) suggested the existence of a seasonal cycle of transmission of T. cruzi in Dzidzilché. The capture of recently infected opossums during February 1997, confirmed 


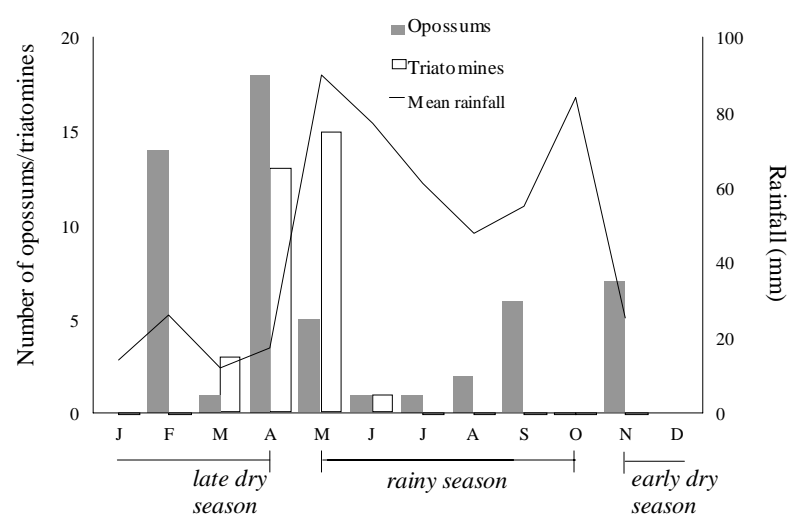

Fig. 4: monthly distribution of the capture of opossums (Didelphis virginiana) and triatomines (Triatoma dimidiata) infected by Trypanosoma cruzi in Dzidzilché, Yucatán, México from April 1996 to May 1998 in relation to season.

the seasonal hypothesis. Similarly, Telford and Tonn (1982) found higher infection prevalence with $T$. cruzi in $D$. marsupialis during late dry season in Venezuela. However, our study showed, for the first time, seasonality in the transmission of $T$. cruzi by $D$. virginiana in México. This timing of transmission is known in other zoonosis, such as leishmaniosis in Colombia and México (ChabléSantos et al. 1995, Travi et al. 1998, Van Wynsberghe et al. 2000). More precise research should be carried out, to confirm our findings since our sample-size was biased toward the dry season.

In Yucatán, people of small villages might be in risk of contracting Chagas disease during the dry season because of three main factors: the attraction of opossums toward peridomestic areas, the affinity of triatomines for opossums, and the seasonality of the transmission cycle of $T$. cruzi. Thus, we recommend that control measures should be concentrated during the dry season and detection programs of infected persons should be carried out at the end of the dry months.

\section{ACKNOWLEDGMENTS}

Technical assistance, equipment, transportation, and physical facilities were provided by The Laboratory of Parasitología, Centro de Investigaciones Regionales Dr. Hideyo Noguchi, University Autonoma de Yucatán. To Raymundo Tzuc for assistance in fieldwork. To Arletty D Arjona Torres, Alma Abán Cauich, Doris Pinto Escalante, Ileana Castillo Zapata, and Jorge Canto Herrera for assistance in laboratory work. To Nicole Van Wynsberghe and Rosa M Flores-Serrano for assistance with the revisions.

\section{REFERENCES}

Aguirre Pequeño E 1947. Presencia de Trypanosoma cruzi en mamíferos y triatomideos de Nuevo León, Monterrey, México. Arch Méd Mexicanos 8: 359-363.

Araujo JC, Jansen AM, Deane MP, Lenzi HL 1996. Histopathological study of experimental and natural infections by Trypanosoma cruzi in Didelphis marsupialis. Mem Inst Oswaldo Cruz 91: 609-618.

Barrera-Pérez MA, Rodríguez-Félix ME, Guzmán-Marín ES, Zavala-Velázquez JE 1990. Enfermedad de Chagas en el estado de Yucatán. Revisión de casos clínicos en fase aguda de 1970 a 1989. Rev Biomed (México) 1: 185-195.

Begon M 1979. Investigating Animal Abundance: Capture-recapture for Biologists, University Park Press, Baltimore, 97 pp.

Chablé-Santos JB, Van Wynsberghe NR, Canto-Lara B, AndradeNarváez FJ 1995. Isolation of Leishmania (L.) mexicana from wild rodents and their possible role in the transmission of localized cutaneous leishmaniasis in the State of Campeche, Mexico. Am J Trop Med Hyg 53: 141-145.

Domínguez A, Ricárdez JR, Espinoza E 1990. Estudio de reservorios silvestres del Trypanosoma cruzi en la reserva ecológica de "El Zapotal", Chiapas, México. Bol Chil Parasitol 45: 8-12.

Downie NM, Heath RW 1971. Métodos Estadísticos Aplicados, Ediciones del Castillo S.A, Madrid, 373 pp.

Flores JS, Espejel I 1994. Tipos de Vegetación de la Península de Yucatán. Etnoflora Yucatanense, Fasc. 3, Universidad Autónoma de Yucatán, Mérida, México, 135 pp.

Gardner AL 1973. The systematics of the genus Didelphis (Marsupialia:Didelphidae) in North and Middle America. Special Publ Mus Texas Tech Univ 4: 1-81.

Galavíz-Silva L, Arredondo-Cantú JM 1992. Primer reporte de Neotoma micropus (Rodentia) como reservorio de Trypanosoma cruzi en México. Bol Chil Parasitol 47: 54-57.

Guzmán-Marín ES, Barrera-Pérez MA, Rodríguez-Félix ME, Zavala-Velázquez JE 1992. Hábitos biológicos de Triatoma dimidiata en el estado de Yucatán, México. Rev Biomed (México) 3: 125-131.

Hossler RJ, McAninch JB, Harder JD 1994. Maternal denning behavior and survival juveniles in opossums in southeastern New York. J Mammal 75: 60-70.

Hunsaker D II 1977. The Biology of Marsupials, Academic Press, New York, 537 pp.

Jones Jr JK, Genoways HH, Smith JD 1974. Annotated checklist of mammals of the Yucatan Peninsula, Mexico. III. Marsupialia, Insectivora, Primates, Edentata, Lagomorpha. Occas Papers Mus Texas Tech Univ 23: 1-12.

Lent H, Wygodzinsky P 1979. Revision of the Triatominae (Hemiptera:Reduviidae) and their significance as vectors of Chagas disease. Bull Am Mus Nat Hist 163: 125-520.

Miles MA 1976. A simple method of tracking mammals and locating triatomine vectors of Trypanosoma cruzi in amazonian forest. Am J Trop Med Hyg 25: 671-674.

Petrides GA 1949. Sex and age determination in the opossum. J Mammal 30: 364-378.

Pietrzak S, Pung O 1998. Trypanosomiasis in raccoons from Georgia. J Wildlife Dis 34: 132-136.

Pinho AP, Cupolillo E, Mangia RH, Fernandes O, Jansen AM 2000. Trypanosoma cruzi in the sylvatic environment: distinct transmission cycles involving two sympatric marsupials. Trans R Soc Trop Med Hyg 94: 509-514.

Quintal RE, Polanco GG 1977. Feeding preferences of Triatoma dimidiata maculipennis in Yucatán, México. Am J Trop Med Hyg 26: 176-178.

Salazar Schettino PM, Bucio-Torres MI, De Haro-Ortega I, Tay-Zavala J, Alonso-Guerrero T 1987. Reservorios y transmisores de Trypanosoma cruzi en el estado de Oaxaca. Sal Pub Mex 29: 26-32.

Solís-Franco RR, Romo-Zapata JA, Martínez-Ibarra JA 1997. Wild reservoirs infected by Trypanosoma cruzi in the ecological park "El Zapotal”, Tuxtla Gutiérrez, Chiapas, México. Mem Inst Oswaldo Cruz 92: 163-164.

Schweigmann NJ, Pietrokovsky S, Bottazzi V, Conti O, Wisnivesky-Colli 1995. Interaction between Didelphis albiventris and Triatoma infestans in relation to Trypanosoma cruzi transmission. Mem Inst Oswaldo Cruz 90: 679682. 
Telford Jr SR, Tonn R 1982. Dinámica de Trypanosoma cruzi en poblaciones de un reservorio primario, Didelphis marsupialis, en los llanos altos de Venezuela. Bol Of Sanit Panam 93: 341-364.

Travi BL, Osorio I, Becerra MT, Adler GH 1998. Dynamics of Leishmania chagasi infection in small mammals of the undisturbed and degraded tropical dry forests in northern Colombia. Trans $R$ Soc Trop Med Hyg 92: 275-278.

Van Wynsberghe NR, Canto-Lara SB, Damián-Centeno AG, Itzá-Ortiz MF, Andrade-Narváez FJ 2000. Retention of Leishmania (Leishmania) mexicana in naturally infected rodents from the State of Campeche, México. Mem Inst Oswaldo Cruz 95: 595-600.

WHO-World Health Organization 1991. Control of Chagas Disease, Technical Report Series No. 811, Geneva, 95 pp.

Wisnivesky-Colli C, Schweigmann NJ, Alberti A, Pietrokovsky SM, Conti O, Montoya S, Riarte A, Rivas C 1992. Sylvatic American trypanosomiasis in Argentina. Trypanosoma cruzi infection in mammals from the Chaco forest in Santiago del
Estero. Trans R Soc Trop Med Hyg 86: 38-41.

Yaeger RG 1971. Transmission of Trypanosoma cruzi infection to opossums via the oral route. J Parasitol 57: 1375-1376.

Zavala-Castro JE 1992. Molecular characterization of Mexican stocks of Trypanosoma cruzi using total DNA. Am J Trop Med Hyg 47: 201-209.

Zavala-Velázquez JE, Barrera-Pérez MA, Rodríguez-Félix ME, Guzmán-Marín ES, Ruiz-Piña HA 1996. Infection by Trypanosoma cruzi in mammals in Yucatan, Mexico: a serological and parasitological study. Rev Inst Med Trop São Paulo 38: 289-292.

Zeledón R, Solano G, Sáenz GS, Swartzwelder JC 1970. Wild reservoirs of Trypanosoma cruzi with special mention of the opossum, Didelphis marsupialis, and its role in the epidemiology of Chagas disease in an endemic area of Costa Rica. J Parasitol 56: 38 .

Zeledón R, Solano G, Zúñiga A, Swartzwelder JC 1973. Biology and ethology of Triatoma dimidiata (Latreille, 1811). J Med Entomol 10: 363-370. 